\section{Case Reports in Dermatology}

Published on Ine: November 14, 2016

(C) 2016 The Author(s)

Published by S. Karger AG, Basel

www.karger.com/cde

This article is licensed under the Creative Commons Attribution-NonCommercial 4.0 International License (CC BY-NC) (http://www.karger.com/Services/OpenAccessLicense) Usage and distribution for commercial purposes requires written permission.

\title{
Scleroderma with Nodular Scleroderma
}

\author{
Chutika Srisuttiyakorn Kobkul Aunhachoke \\ Division of Dermatology, Department of Medicine, Phramongkutklao Hospital, \\ Bangkok, Thailand
}

\section{Keywords}

Keloidal scleroderma $\cdot$ Nodular scleroderma $\cdot$ Scleroderma

\begin{abstract}
Background: Nodular scleroderma is a rare variant of scleroderma which can occur in connection with systemic sclerosis or morphea. A biopsy from the lesion can demonstrate the scleroderma pattern, i.e., keloid pattern or mixed type. Treatment is challenging, and several treatments modalities have been reported with unsatisfactory results. Main Observations: We present a case of systemic sclerosis in a 50-year-old female who developed nodular scleroderma in the absence of deterioration of the scleroderma condition. Although no additional treatment was given, the lesions remained stable without progression. Conclusions: Although this condition is rare, it has been reported sporadically, and clinicians should be able to recognize this variant in cases of scleroderma presenting with firm nodules or plaques.
\end{abstract}




\section{Case Report}

A 50-year-old female presented with a 1-year history of systemic sclerosis and interstitial lung disease. Her current medications were prednisolone $5 \mathrm{mg}$, cyclophosphamide 75 $\mathrm{mg}$, amlodipine $20 \mathrm{mg}$, sildenafil $50 \mathrm{mg}$, and aspirin $80 \mathrm{mg}$ daily. Ten months later, she developed multiple asymptomatic papules on the neck, abdominal wall, and back (Fig. 1, Fig. 2). The lesions increased in size and number, and some lesions coalesced with plaques. She denied a previous history of surgery or trauma at the affected sites. Neither a personal history nor a family history of keloid was confirmed.

The physical examinations demonstrated sclerotic skin changes on the face, trunk, and extremities with sclerodactyly, digital pitting scars, and Raynaud's phenomenon. There were multiple, nontender, firm skin-colored papules and plaques scattered on the neck, abdominal wall, and back. The laboratory tests revealed positive antinuclear antibody in a homogenous pattern (titer 1:320) and positive anti-Scl70. The complete blood count, renal function, and liver function tests were unremarkable.

A 4-mm punch biopsy from the lesion on the neck was performed. The biopsy revealed thick sclerotic collagen fibers in the mid-dermis (Fig. 3). Mucicarmine staining to indicate the presence of mucin was negative. Thus, the findings were compatible with scleroderma.

\section{Discussion}

Our patient was diagnosed with scleroderma in the presence of nodular scleroderma. Nodular or keloidal scleroderma is a rare variant of scleroderma [1-5]. These terms can be used interchangeably. Nevertheless, in the literature, they are sometimes used as distinctive entities. The term "nodular scleroderma" is used when the pathological change resembles scleroderma, and the term "keloidal scleroderma" is used when the pathological change shows hyalinization of thick sclerotic collagens similar to keloid $[1,6,7]$.

Nodular or keloidal scleroderma have been reported in either systemic sclerosis or localized scleroderma, usually 6 months after the presentation of systemic sclerosis $[1-3,8-$ 17]. However, also the presence of nodular scleroderma before the onset of systemic sclerosis has been reported [12]. This condition can be found in systemic sclerosis patients either with or without active systemic involvements [1, 2, 8, 11-19].

The characteristic clinical presentations were firm nodules or plaques resembling keloid, distributed predominantly on the proximal extremities, i.e., on the chest, back, and neck. Nodular or keloidal scleroderma usually occur in middle-aged females (Table 1) $[1,4,8,11$ 14, 16-18]. Variable histopathologic changes have been reported to include characteristics of keloid or hypertrophic scars, of morphea, or of both morphea and keloid [1, 19].

The pathogenesis of this condition is still unclear. Complex interactions between cytokines, matricellular proteins, and local factors (minor trauma and vascular insufficiency) should be determined $[2,19,20]$. A role of pathogens, including acid-fast bacteria or chronic HCV infection, has been reported $[11,14,21]$. Currently, the increased activity of fibroblasts is believed to play a role. Yamamoto et al. [19] mentioned the role of increasing connective tissue growth factor (CTGF) in tissue fibrosis. Nonetheless, an increase in CTGF was identified both in the nodular lesions and in skin with scleroderma. Consequently, the increase in 
CTGF alone may not be the sole contributor to the pathogenesis of fibrosis in the lesions. Moinzadeh et al. [22] demonstrated increasing cartilage oligomeric matrix protein (COMP), collagen XII, and fibrillin-1 in nodular scleroderma lesions compared to perilesional skin and healthy skin. COMP is induced by TGF- $\beta$, which is an important cytokine in stimulating fibrosis in scleroderma and is involved in modulating the dermal collagen network as well as in sustaining fibroblast activation [22]. Additionally, highly expressed COMP has been demonstrated in keloid [23].

Since our case presented with multiple skin-colored papules and plaques, a differential diagnosis that should be considered was localized cutaneous mucinosis, which can be found as a coexisting condition with systemic sclerosis or morphea [24-28]. However, the diagnosis of localized cutaneous mucinosis should be confirmed by mucin deposition in a skin biopsy.

The treatment of nodular scleroderma is challenging. Several treatment modalities are mentioned in the literature, including topical or intralesional steroids, systemic steroids, topical calcipotriene, psoralen photochemotherapy, cyclosporine, D-penicillamine, methotrexate, extracorporeal photochemotherapy, and excision [1, 2, 4, 11-18, 29, 30]. However, these treatment modalities have shown unsatisfying results. A review of the reports on nodular or keloidal scleroderma in the past 10 years (Table 1) revealed that 1 case demonstrated stable nodular scleroderma without any specific treatment [16]. Interestingly, immunosuppressive agents that have previously been received cannot prevent the development of nodular or keloidal scleroderma [11-13, 16].

The condition of systemic sclerosis in our case has been stable, and the patient was not concerned about its appearance. Therefore, we decided to closely observe and monitor her for any progression of the lesions. After 4 months, the lesions have remained stable.

In conclusion, we presented a case of systemic sclerosis with multiple lesions of nodular scleroderma. Although this condition is rare, it has been reported sporadically, and it should be considered in scleroderma patients clinically presenting with firm nodules or plaques.

\section{Acknowledgements}

The authors are grateful to Dr. Pinyapat Kanechorn-Na-Ayuthaya, MD, for reading and correcting the manuscript.

\section{Statement of Ethics}

The patient gave her written informed consent.

\section{Disclosure Statement}

The authors report no conflicts of interest. This research did not receive any specific grant from funding agencies in the public, commercial, or not-for-profit sectors. 


\section{References}

1 Wriston CC, Rubin AI, Elenitsas R, Crawford GH: Nodular scleroderma: a report of 2 cases. Am J Dermatopathol 2008;30:385-388.

2 Mizutani H, Taniguchi H, Sakakura T, et al: Nodular scleroderma: focally increased tenascin expression differing from that in the surrounding scleroderma skin. J Dermatol 1995;22:267-271.

-3 Perez-Wilson J, Pujol RM, Alejo M, et al: Nodular (keloidal) scleroderma. Int J Dermatol 1992;31:422423.

4 Ling TC, Herrick AL, Andrew SM, et al: Keloidal scleroderma. Clin Exp Dermatol 2003;28:171-173.

5 Sasaki T, Denpo K, Ono H, et al: Nodular scleroderma in systemic sclerosis under D-penicillamine therapy. J Dermatol 1992;19:968-971.

-6 Barzilai A, Lyakhovitsky A, Horowitz A, et al: Keloid-like scleroderma. Am J Dermatopathol 2003;25:327-330.

7 Rencic A, Brinster N, Nousari CH: Keloid morphea and nodular scleroderma: two distinct clinical variants of scleroderma? J Cutan Med Surg 2003;7:20-24.

8 Cannick L 3rd, Douglas G, Crater S, Silver R: Nodular scleroderma: case report and literature review. J Rheumatol 2003;30:2500-2502.

Hsu S, Lee MW, Carlton S, et al: Nodular morphea in a linear pattern. Int J Dermatol 1999;38:529-530. Micalizzi C, Parodi A, Rebora A: Morphoea with nodular lesions. Br J Dermatol 1994;131:298-300. Melani L, Caproni M, Cardinali C, et al: A case of nodular scleroderma. J Dermatol 2005;32:1028-1031. Heath CR, David JN, Taylor SC: Nodular scleroderma presenting as multiple spontaneous keloidal scars. J Am Acad Dermatol 2012;66:e245-e246. Kassira S, Jaleel T, Pavlidakey P, Sami N: Keloidal scleroderma: case report and review. Case Rep Dermatol Med 2015;2015:635481.

14 Kokpol C, Chu EY, Rutnin S: Nodular scleroderma in a patient with chronic hepatitis C virus infection: a coexistent or causal infection? Cutis 2015;96:E19-E22. Spierings J, Verstraeten VL, Vosse D: Nodular scleroderma. Arthritis Rheumatol 2015;67:3157. Le EN, Junkins-Hopkins JM, Sherber NS, Wigley FM: Nodular/keloidal scleroderma: acquired collagenous nodules in systemic sclerosis. J Rheumatol 2012;39:660-661. Sen S, Biswas T, Banerje G, Biswas S: Keloids in scleroderma - keloidal scleroderma: a unique entity. Indian J Dermatol 2013;58:153-154. 2013;88(6 suppl 1):75-77. Yamamoto T, Sawada Y, Katayama I, Nishioka K: Nodular scleroderma: increased expression of connective tissue growth factor. Dermatology 2005;211:218-223. Yamamoto T, Sakashita S, Sawada Y, et al: Possible role of epidermal growth factor in the lesional skin of nodular morphea. Acta Derm Venereol 1998;78:312-313.

-21 Cantwell AR Jr, Rowe L, Kelso DW: Nodular scleroderma and pleomorphic acid-fast bacteria. Arch Dermatol 1980;116:1283-1290.

22 Moinzadeh P, Agarwal P, Bloch W, et al: Systemic sclerosis with multiple nodules: characterization of the extracellular matrix. Arch Dermatol Res 2013;305:645-652.

-23 Inui S, Shono F, Nakajima T, et al: Identification and characterization of cartilage oligomeric matrix protein as a novel pathogenic factor in keloids. Am J Pathol 2011;179:1951-1960.

$\checkmark 24$ Yasuma A, Shibagaki R, Yagyu R, et al: Coexistence of linear morphea and nodular mucinosis. J Dermatol 2013;40:937-938.

-25 Sawada Y, Seishima M, Funabashi M, et al: Papular mucinosis associated with scleroderma. Eur J Dermatol 1998;8:497-500.

-26 Rongioletti F, Rampini P, Parodi A, Rebora A: Papular mucinosis associated with generalized morphoea. Br J Dermatol 1999;141:905-908.

27 Chun SI, Cho NJ: Linear morphea with secondary cutaneous mucinosis. Am J Dermatopathol 1992;14:546-548.

28 Van Zander J, Shaw JC: Papular and nodular mucinosis as a presenting sign of progressive systemic sclerosis. J Am Acad Dermatol 2002;46:304-306.

29 Wollina U, Looks A, Lange D: Extracorporeal photochemotherapy in nodular scleroderma. Br J Dermatol 1998;139:559-560.

30 Wollina U: Nodular scleroderma - successful treatment with extracorporeal photo chemotherapy. Indian J Dermatol 2000;45:157-160. 


\section{Case Reports in Dermatology} www.karger.com/cde

Srisuttiyakorn and Aunhachoke: Scleroderma with Nodular Scleroderma

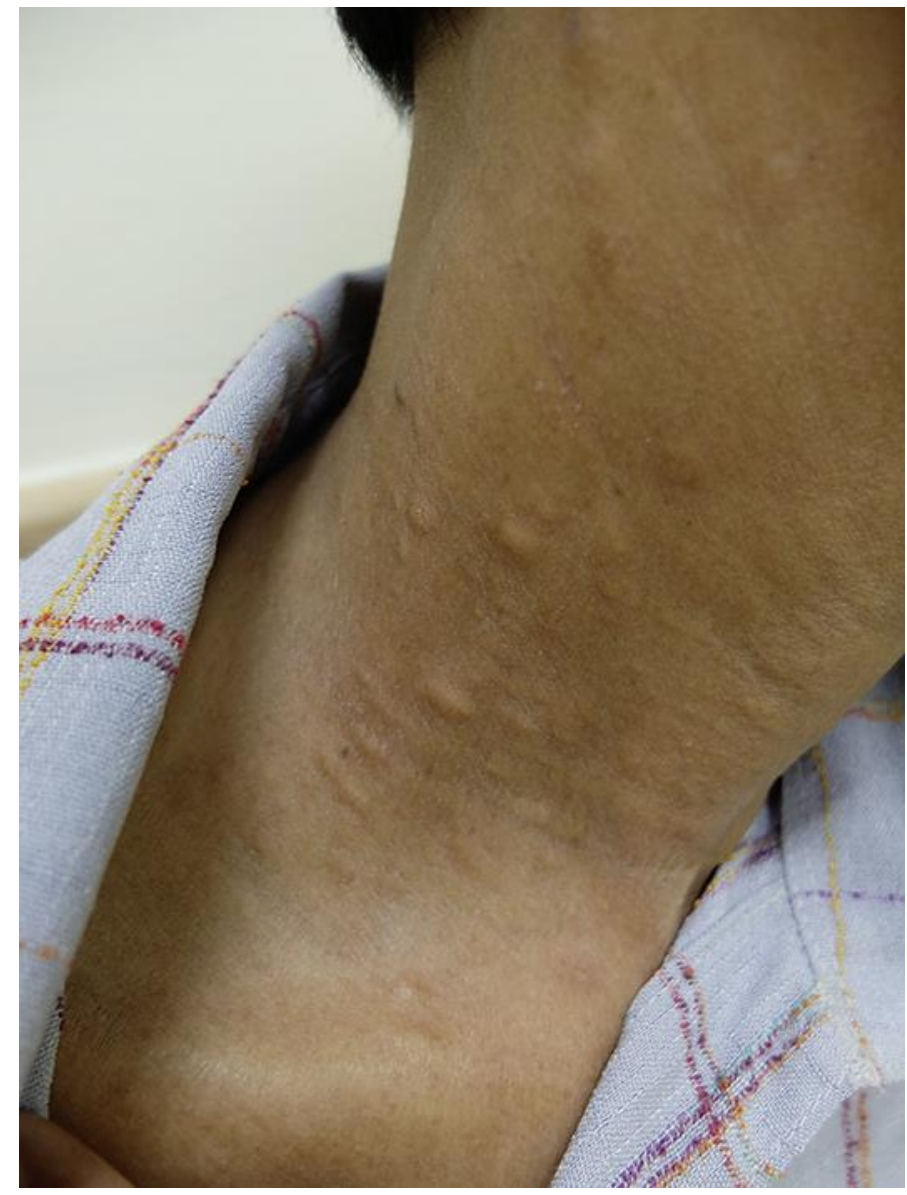

Fig. 1. Multiple skin-colored papules and plaques on the neck. 


\section{Case Reports in Dermatology}

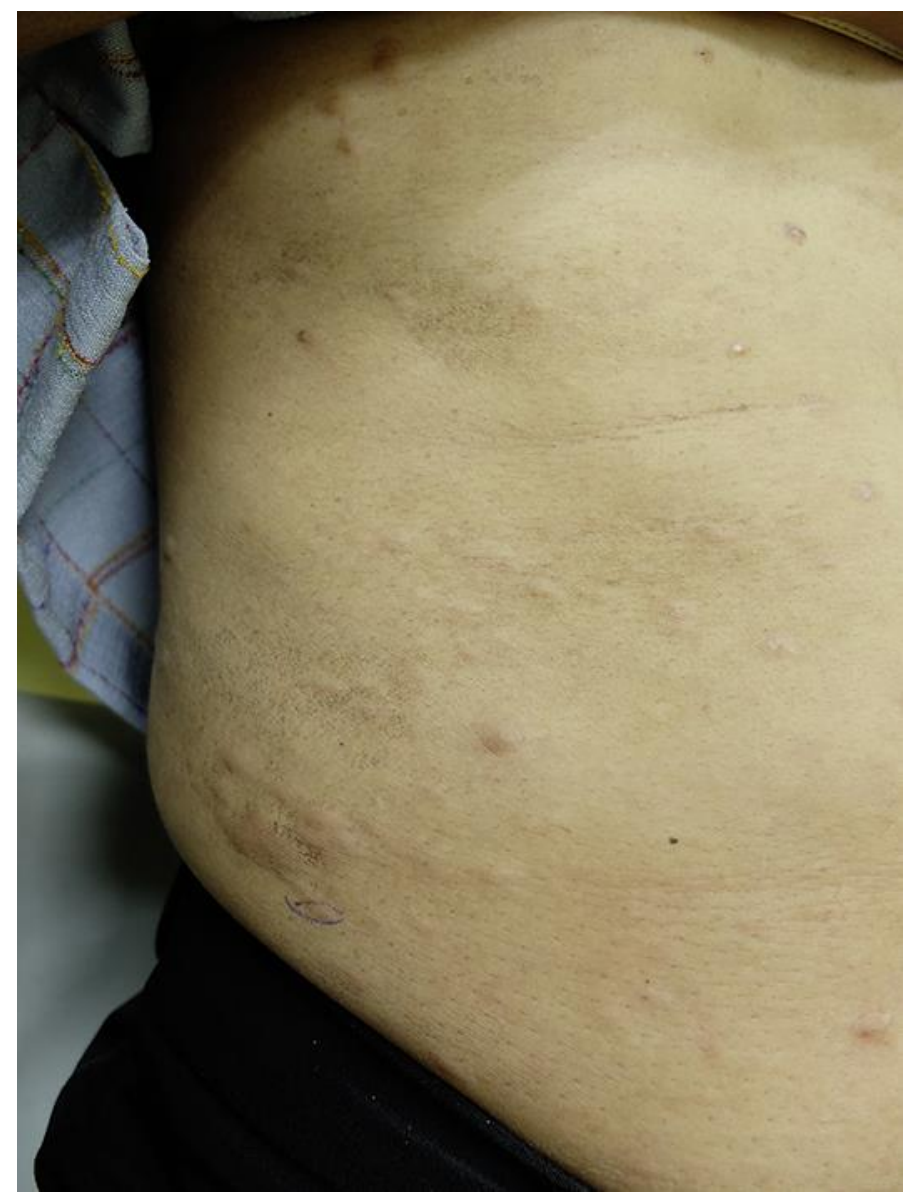

Fig. 2. Multiple skin-colored papules and plaques on the abdominal wall. 


\section{Case Reports in Dermatology}

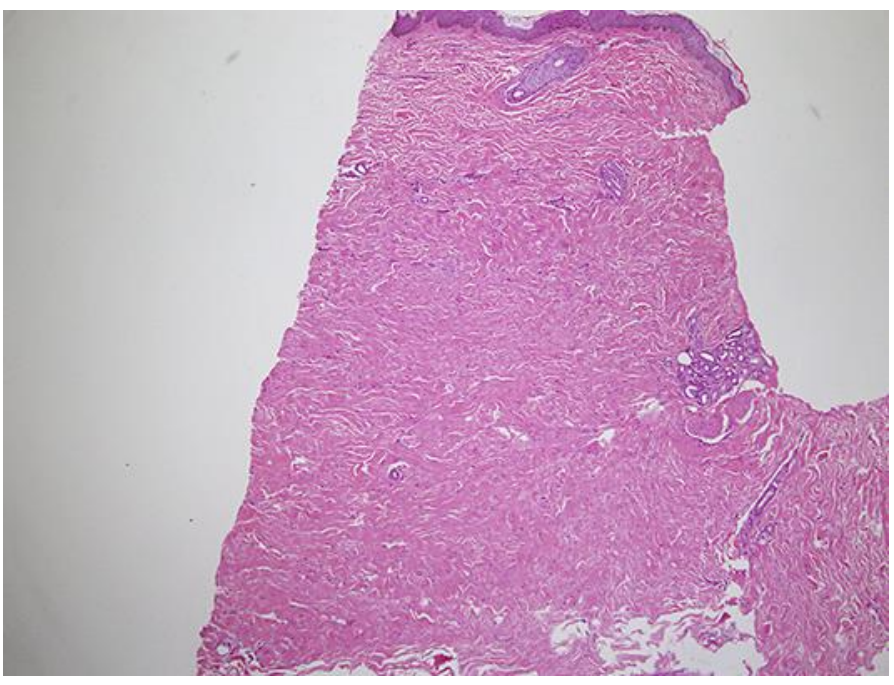

Fig. 3. There are thick, sclerotic collagen fibers in the mid-dermis, extending to the deep dermis and superficial part of the subcutaneous layer. HE, $\times 40$. 
Table 1. Demographic characteristics and treatments of the reported cases of nodular or keloidal scleroderma in the past 10 years

\begin{tabular}{|c|c|c|c|c|c|c|c|}
\hline $\begin{array}{l}\text { First author, } \\
\text { year [ref.] }\end{array}$ & Sex & $\begin{array}{l}\text { Age, } \\
\text { years }\end{array}$ & $\begin{array}{l}\text { Distribution } \\
\text { of lesions }\end{array}$ & Diagnosis & $\begin{array}{l}\text { Duration } \\
\text { of lesions }\end{array}$ & Treatments & Results \\
\hline $\begin{array}{l}\text { Kassira, } \\
2015[13]\end{array}$ & female & 40 & $\begin{array}{l}\text { chest, neck, } \\
\text { abdomen }\end{array}$ & $\begin{array}{l}\text { localized } \\
\text { scleroderma }\end{array}$ & 4 weeks & $\begin{array}{l}\text { MTX } 17.5 \mathrm{mg} / \text { week for } \\
6 \text { weeks }\end{array}$ & $\begin{array}{l}\text { reduced } \\
\text { firmness, no } \\
\text { new lesions }\end{array}$ \\
\hline $\begin{array}{l}\text { Kokpol, } \\
2015[14]\end{array}$ & female & 63 & neck, trunk & $\begin{array}{l}\text { systemic } \\
\text { sclerosis, } \\
\text { chronic HCV } \\
\text { infection }\end{array}$ & 1 year & $\begin{array}{l}\text { intralesional TA } 5-10 \mathrm{mg} / \mathrm{mL} \\
\text { and ultrapotent topical steroid } \\
\text { cream }\end{array}$ & $\begin{array}{l}\text { modest clinical } \\
\text { improvement }\end{array}$ \\
\hline $\begin{array}{l}\text { Spierings, } \\
2015[15]\end{array}$ & male & 76 & $\begin{array}{l}\text { back, } \\
\text { abdomen }\end{array}$ & $\begin{array}{l}\text { systemic } \\
\text { sclerosis, } \\
\text { monoclonal } \\
\text { gammopathy }\end{array}$ & 1 year & n.a. & n.a. \\
\hline $\begin{array}{l}\text { Stadler, } \\
2013[18] \\
\end{array}$ & female & 44 & $\begin{array}{l}\text { trunk, back, } \\
\text { neck }\end{array}$ & $\begin{array}{l}\text { systemic } \\
\text { sclerosis }\end{array}$ & 6 years & systemic steroids, MTX, PUVA & n.a. \\
\hline $\begin{array}{l}\text { Sen, } 2013 \\
{[17]}\end{array}$ & female & 26 & $\begin{array}{l}\text { chest, upper } \\
\text { extremities, } \\
\text { trunk }\end{array}$ & $\begin{array}{l}\text { systemic } \\
\text { sclerosis }\end{array}$ & 6 years & n.a. & n.a. \\
\hline $\begin{array}{l}\text { Heath, } \\
2012[12]\end{array}$ & female & 13 & $\begin{array}{l}\text { face, neck, } \\
\text { trunk, } \\
\text { extremities }\end{array}$ & $\begin{array}{l}\text { systemic } \\
\text { sclerosis }\end{array}$ & 2 years & $\begin{array}{l}\text { calcipotriene/betamethasone } \\
\text { dipropionate ointment }\end{array}$ & $\begin{array}{l}\text { soften the } \\
\text { lesions }\end{array}$ \\
\hline $\begin{array}{l}\text { Le, } 2012 \\
{[16]}\end{array}$ & female & 70 & $\begin{array}{l}\text { abdomen, } \\
\text { neck, upper } \\
\text { back, chest }\end{array}$ & $\begin{array}{l}\text { systemic } \\
\text { sclerosis }\end{array}$ & 1 year & $\begin{array}{l}\text { surgical removal of large } \\
\text { nodules }\end{array}$ & $\begin{array}{l}\text { no report of } \\
\text { recurrent } \\
\text { disease }\end{array}$ \\
\hline $\begin{array}{l}\text { Le, } 2012 \\
{[16]}\end{array}$ & female & 45 & $\begin{array}{l}\text { abdomen, neck, } \\
\text { upper chest }\end{array}$ & $\begin{array}{l}\text { localized } \\
\text { scleroderma }\end{array}$ & 3 years & no treatment & stable lesion \\
\hline $\begin{array}{l}\text { Wriston, } \\
2008[1]\end{array}$ & male & 51 & $\begin{array}{l}\text { mid-chest, } \\
\text { back }\end{array}$ & $\begin{array}{l}\text { systemic } \\
\text { sclerosis }\end{array}$ & 8 years & intralesional TA $10 \mathrm{mg} / \mathrm{mL}$ & no change \\
\hline $\begin{array}{l}\text { Wriston, } \\
2008[1]\end{array}$ & female & 30 & $\begin{array}{l}\text { chest, arms, } \\
\text { thighs }\end{array}$ & $\begin{array}{l}\text { systemic } \\
\text { sclerosis }\end{array}$ & 2 years & intralesional TA $10 \mathrm{mg} / \mathrm{mL}$ & $\begin{array}{l}\text { modest } \\
\text { improvement }\end{array}$ \\
\hline $\begin{array}{l}\text { Melani, } \\
2005[11]\end{array}$ & female & 22 & $\begin{array}{l}\text { trunk, neck, } \\
\text { abdomen, } \\
\text { thighs }\end{array}$ & $\begin{array}{l}\text { systemic } \\
\text { sclerosis }\end{array}$ & 2 years & $\begin{array}{l}\text { D-penicillamine, systemic } \\
\text { steroid }\end{array}$ & no change \\
\hline $\begin{array}{l}\text { Yamamoto, } \\
2005 \text { [19] }\end{array}$ & male & 29 & arms, chest & $\begin{array}{l}\text { systemic } \\
\text { sclerosis }\end{array}$ & months & n.a. & n.a. \\
\hline $\begin{array}{l}\text { Yamamoto, } \\
2005 \text { [19] }\end{array}$ & male & 34 & chest & $\begin{array}{l}\text { systemic } \\
\text { sclerosis }\end{array}$ & $\begin{array}{l}\text { several } \\
\text { months }\end{array}$ & n.a. & n.a. \\
\hline $\begin{array}{l}\text { Yamamoto, } \\
2005 \text { [19] }\end{array}$ & female & 60 & neck, back & $\begin{array}{l}\text { systemic } \\
\text { sclerosis }\end{array}$ & months & n.a. & n.a. \\
\hline
\end{tabular}

n.a., not available; MTX, methotrexate; TA, triamcinolone; PUVA, psoralen photochemotherapy. 